The Japanese Journal of Experimental

Social Psychology. 1985, Vol. 24, No. 2, 149-159

〔資

料]

\title{
共有地の悲劇のシミュレーション実験 ${ }^{1)}$
}

\author{
北海道大学 \\ 佐藤香
}

目的

「共有地の悲劇」に代表される社会的陥せい（social traps) の問題は, Hardin (1968) の論文以来心理学者 のみではなく社会学, 経済学, 政治学等の社会科学の諸 分野に属する多くの研究者の関心を集め，てれまでに各 種の実証的研究がなされて来ている。てれらの研究には 現実に存在する種々の問題の分析も合まれているが，そ の多くは小集団における「シミュレーション実験」であ る。てれらの小集団実験においては，社会的陥せいの問 題を主として個人利益対集団利益の対立の問題として捉 え，二人集団におけるマトリクス・ゲームの延長として 行なわれたものが多い。しかし Edney \& Harper (1978) により指摘されているように，てのようなマトリクス・ ゲームの延長としての小集団実験においては, 社会的陥 せい問題の重要な一側面が抜け落ちている。つまり，て れら実験においては集団成員間の相互传存関係（二人ゲ ームにおいては典型的に利得マトリクスとして表現され る）か所与のものとして被験者に対して与えられており， 被験者の行動はてのような関係ないし集団構造そのもの を変化させることがない。被験者は与えられた環境に対 して「反応」するのみであり，そのような環境自体に働 きかけ環境自体を変化させる可能性を例奪されているわ けである。しかしながら, 環境に対してたんに受動的に 反応するだけのものとして被験者を捉えるてのようなア プローチは, 共有地の悲劇問題あるいは社会的宿せい問 題の基本的論理構造と矛盾していると言わざるを得ない。 てれらの問題においては, メンパーの行動そのものによ りもたらされる環境の変化一一例えば共有資源過剩利用 によりもたらされる資源の荒廃——に問題の核心がある からである。従って共有地の悲劇ないし社会的陌せい問 題の研究においては, たんに個人利益対集団利益の対立 という点から静的に問題を提えるだけでは不十分であり，
てのような利益の対立が時間の経過とともに集団成員の 行動により変化していくという側面に目を向ける必要が ある。

本研究の主要な目的は，てのような共有地ジレンマな いし社会的陥せい問題の重要な側面をなす動的フィード バックを可能とする実験方法を開発し，そのような方法 の有効性を検討するととにある。本研究においては, コ ンピューターを用いて共有地の悲劇のシミュレーション を行なうてとによりてのような目的の達成をはかった。 てのシミュレーションにおいては, コンピューターのデ ィスプレー上に表現された「共有の牧草地」を被験者が 利用する程度に応じて, 牧草地の荒廃の度合が変化する ようにデザインされている。とのてとにより被験者の行 動が環境そのものを変化させるという側面が実験に導入 されることになる。具体的な実験方法については，以下 に記述する。

本研究で開発された実験方法の有効性を検討するため の材料を提供するために，今回の実験では，集団成員間 に「地位」の差を導入し，異なった「地位」を占める成 員が環境の変化にどのように対応して行くかを調べた。 Equity に関するてれまでの研究においては，地位の低 い者あるいはインプットのレヴェルの低い者は報酬の平 等な分配を公正であると考えるのに対して，地位の高い 者あるいはインプットのレヴェルの高い者は地位あるい はインプットのレヴェルに応じた報酬の分配を公正と考 える傾向にあるてとが知られている(例えば, Chertkoff, 1970; Cook \& Yamagishi, 1983)。

今回の実験においても被験者がてのように考元行動す れば，異なった地位にある被験者により公正と考えられ る報酬の総額がインフレートする，つまり共有地が適性 な利用度を越えて利用される可能性が生じる。乙の場合 には，被験者による公正分配の追求と集団全体の利益と が対立するてとになる。てのような葛藤のもとで地位

1）本論文は，昭和54年度北海道大学文学研究科修士論文をまとめたものである。本論文の作成にあたり多大な 御助言と御指導をいたたいた，北海道大学文学部行動科学科戸田正直教授および山岸俊男助教授に深謝いた します。 
の高い者が現状維持をはかり地位の低い者があくまでも 「社会的公正」の追求をはかれば，資源の荒廃は避けら れない。本実験においては地位の異なった被験者がての ような状況のもとでどのように異なった行動を取るかに ついての仮説は立てられていないが，異なった地位の被 験者が実際にどのような行動を取るかを調べることによ り, 社会的公正と集団全体の利益との関係を研究するに あたり，ててで開発された実験方法が有効性を持つかど うかを検討する。

$$
\text { 方法 }
$$

3 名一組の被験者が共有の牧草地に羊を放牧し，そ乙 から利益を上げるという設定の下に実験は行なわれた。 この共有の牧場は, Hardin (1968) により論じられた共 有地の基本的特性を備えている。すなわち個々の被験者 は自由に自分の羊の頭数を増堿出来るが，共有地に放牧 されている羊の総数が増えるにつれ牧草地の荒廃が進行 し，羊の大量死をともなうカタストロフィーの発生する 可能性が増大する。具体的には, カタストロフィーによ
る羊の大量死の可能性は羊の総数が 297 頭（牧場におけ る羊の最大収容能力の $75 \%$ ）になると $1 \%$ 生じ, 以後羊 の総数が 1 頭增加するにつれカタストロフィーの確率も $1 \%$ づつ増加する2)。カタストロフィーが発生した場合

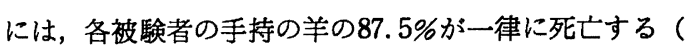
これらの数字そのものを実験的に操作するととも可能で あるが，今回の実験においては上述の数字を悉意的に用 いた。今回の実験の目的はてれらの数字が被験者の行動 に与える影響を調べるとにあるのではなく，被験者の 行動により生じる環境の変化一一牧場の荒廃一一を実験 場面に導入するととにある)。また，実験場面の設定に 現実性を持たせるため, すべての羊は 1 試行につき $3 \%$ の確率で自然死するように設定されている。共有の牧草 地の利用状況は各被験者のコンピューター端末ディスプ レー上に示される (Fig.1 を参照されたい)。各被験者 のディスプレー画面の大半は $22 \times 18=396$ の点で占めら れている。てれらの点は牧場の物理的スペースを表して おり，牧場に羊が放牧されるとてれらの点上に羊の所有 者のシンボル（A，B，Cのアルファベットで代表され

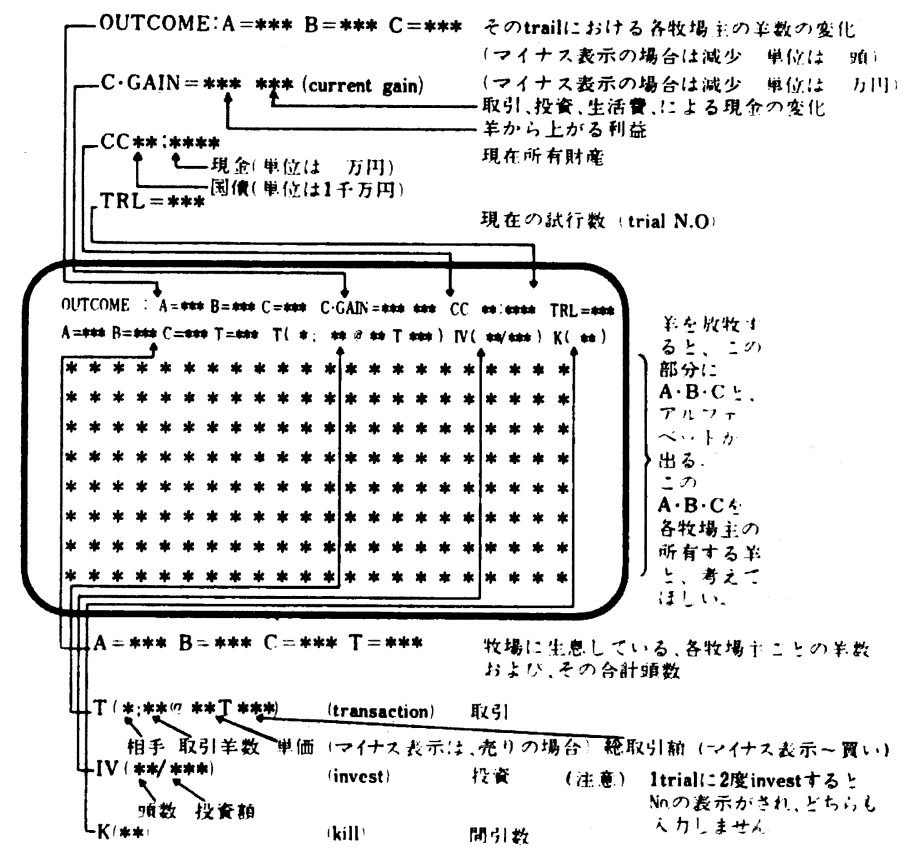

Fig. 1. インストラクション用紙に示されたディスプレーの例

2) ある試行における総羊数を $\mathrm{N}$ とると，その試行でのカタストロフィーの発生確率は $\mathrm{p}=\mathrm{N}-296 \%$ 与え られる。たたし発生確率は $\mathrm{N} \geqq 297$ という条件でのみ生しる。毎試行ての確率にもとついてカタストロフィ

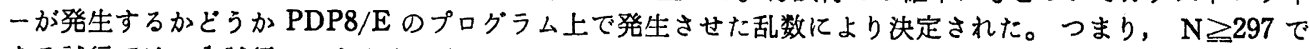
ある試行では，1武行につきカタストロフィーの発生する可能性が $\mathrm{N}-296 \%$ げある。また，羊の数が多 いほどカタストロフィー発生の可能性は高く，牧場の最大収容羊数である396頭に達すると，確率 $100 \%$ とな り必ずカタストロフィーに発生する。 
佐藤：共有地の悲劇のシミュレーション実殹

る）が羊の数だけ表示される。被験者はディスプレー上 に示された牧場の利用状況を見ながら自分の羊の数を決 定して行く。羊毛の収穕のサイクルを40秒から成る 1 試 行とし, 実験全体は 100 試行から成り立っている。各被 験者は実験開始時に1000万円の資本金を与えられ，各試 行において，1頭あたり10万円の価格でそれぞれ何頭の 羊を仕入れるかを決定する。これらの羊は次の試行から 羊毛収穫の利益として 1 頭あたり毎試行 1 万円の利益を 生み出すととになる。実験終了時には各被験者の手持ち の羊は仕入れ価格と同額で換金され，実験終了時におけ る各被験者の利益の総額に応じて報酬が現金で支払われ る。

以上が実験の 基本的な設定であるが，今回の実験で はてれ以外に次のようなオプションが導入されている。

(1) 3 名の被験者は羊を仕入れるだけでなく, 被験者相 互の間で手持の羊を売買するととが出来る。（2）また被 験者は共有牧場内の自分の羊を毎試行任意の頭数だけ間 引くととにより, 牧場の荒廃を防ぐ（カタストロフィー の確率を引き下げる）乙とが出来る。（3）3名の被験者 はお互いの間で，紙に自由に記したメッセーシの交換を 行なうことが出来る。これらのオプション導入の目的は, これらのオプションが被験者によりどの程度頻繁に用い られ，どの程度共有資源の維持に影䅉するかを調べるこ とにより，今後の実験デザインの参考とするためである。 取引, 間引,メッセージ交換については 1 試行における 回数の制限はないが，仕入れは 1 試行につき 1 度しか許 されていない（これらの情報がどのようにディスプレー 上に表現されたかについては，Fig.1 を参照されたい)。

3 名の被験者の相対的地位は, 名武行毎に仕入れるこ との出来る羊の数を制限することにより操作された。具 体的には, プレーャー A は毎武行最大 15 頭まで仕入れる ととが出来るが，Bは10頭，Cは 5 頭までしか仕入れる ことが出来ない。

装 置 ミニ・コンピューター (PDP 8/E) に接続さ れた 4 台の端末（ディスプレーおよびキーボード）の内， 3 台は被験者用，1台は実験者の監視用に用いた。

手 続 被験者はまず別室でインストラクション用紙 を配布され，実験の概要について教示を受けた後，ラン ダムに決定された地位に応じた端末の前に着席する。 3 名の被験者はお互いに間仕切りで隔離されており，お互 いの間での会話は禁止されている。インストラクション 用紙には，先に述べた実験の概要が説明された後，ディ スプレー上の画面についての説明がなされている。ただ しカタストロフィーについてはその可能性についての言 及がなされているだけで, 実際の確率およびその程度に
ついては知らされていない。カタストロフィーの確率を 被験者に知らせることにより被験者の行動がどう変るか は興味ある今後の研究テーマであるが, 現実社会におけ る社会的陥せい問題においては，カタストロフィーの可 能性が完全に知られている場合のほうがむしろまれであ ると言えるにもかかわらず，カタストロフィーの可能性 についての情報が不確実な状況での実験はてれまであま りなされて来なかったので, 今回の実験においてはての ような不確実な状況に焦点をあてた。

被験者は投資（羊の仕入れ）および間引に関する決定 を，端末のキーボードを通して行なう。ただし取引その 他に関するメッセージ交換は，所定の用紙を間仕切の穴 を通して交換するととにより行なった。1 試行は40秒か ら成り，その間に投資に関する決定を一度だけ行なうこ とが出来，また 1 試行毎に羊毛の収穫により利益が生み 出された。1 試行終了時点でコンピューターの情報処理 期間となり，その間（約 2 秒）被験者からの入力は停止 される。

実験の内容およびディスプレーの内容についての説明 がなされた後，キーボード操作に習熟する目的で，10試 行の練習試行がなされ，次に 100 試行の実験試行がなさ れた。実験の進行はすべてミニコンピューターにより制 御され，実験の進行記録は逐次プリンターにより打ち出 された。

\section{結果}

本研究の目的は社会的陷せいについての特定の仮説を 検証することにあるのではなく, 社会的陥せいの実験的 研究のための新しい実験方法を開発し，その有効性を検 討するととにある。従って結果に関しても，組織的な統 計的テストを行なうのではなく, 被験者の行動パターン の記述を主として行なう。

被験者に与えられる実験の目的は財産の最大化にある ので，財産量と被験者の行動との関係を第一に榆討しな ければならない。そてで財産量を対数変換し，被験者の 行動との関係の過程分析を試みたが，明瞭な傾向は示さ れなかった。またグループ間におけるメンバーの財産量 の合計にはあまり顕著な差が見られなかった（最大は第 5 グループの 7839万円， 最小は第 4 グループの 5850万 円)。従って以下の分析においては, 財産量は直接に报 わない。

所有羊数および投資額 Fig. $2 \mathrm{a}-2 \mathrm{~g}$ は，各グループ別 に 100 試行を 5 武行毎の 20 ブロックに分け，それぞれの ブロックにおける 3 名のメンバーおよびグループ全体の 平均所有羊数と投資額（仕入れた羊の数）を示している。 


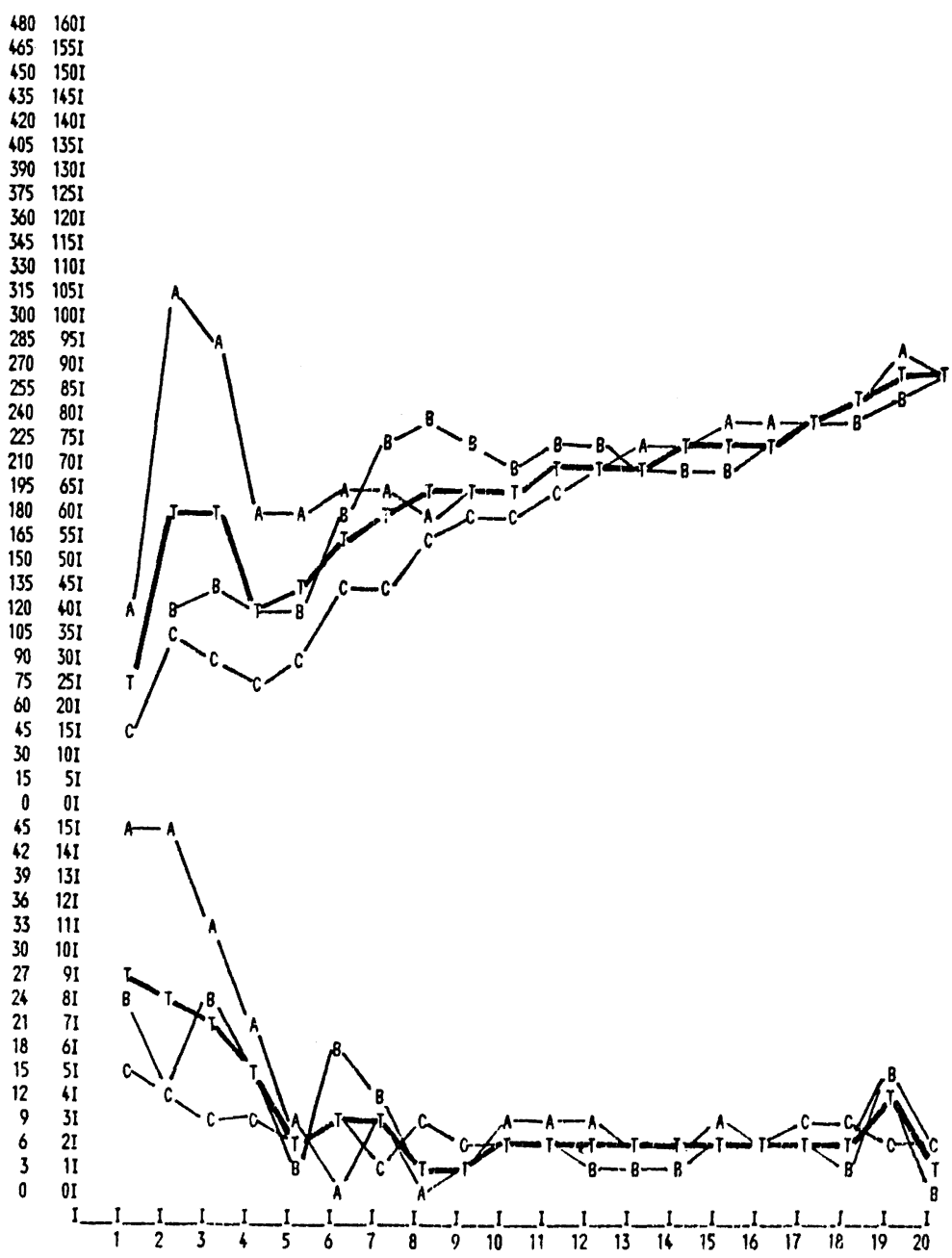

Fig. 2-a 所有羊数・投資量の推移〔第 1 グループ〕

またそれぞれのグループにおけるカタストロフィーの発 生状況は Table 1 に示されている。乙れらの図および 表から次のことが明らかにされる。(1) 第 6 および 7 グ ループを除く他のすべてのグループにおいて（実験開始 時ないしカタストロフィー時から), 時間がたつにつれ, 3 名の被験者の所有羊数の格差が縮小するように変化す る傾向が見られる。第 6,7 グループにおいてはとのよ うな傾向が見られず，ての点に関しててれら二つの群の あいだに顕著な差が存在する。（2）カタストロフィーが 一度しか発生していないグループ（第 $1,5 ， 6,7 ク ゙$ ループ）と，二度発生しているグループ（第 $2 ， 3 ， 4$ グループ）が存在する。てれら二点についてもう少し詳 しく検討することにしたい。
Table 1

\begin{tabular}{|c|c|c|c|}
\hline \multirow{2}{*}{ グループ } & \multirow{2}{*}{$\begin{array}{l}\text { カタストロフィ- } \\
\text { 発生試行番号 }\end{array}$} & \multicolumn{2}{|c|}{ 発生直前圾行 } \\
\hline & & 悇 & 羊 数 \\
\hline 1 & 14 & & 294 \\
\hline \multirow[t]{2}{*}{2} & 15 & & 296 \\
\hline & 90 & & 297 \\
\hline \multirow[t]{2}{*}{3} & 66 & & 337 \\
\hline & 89 & & 308 \\
\hline \multirow[t]{2}{*}{4} & 23 & & 355 \\
\hline & 46 & & 303 \\
\hline 5 & 16 & & 300 \\
\hline 6 & 47 & & 304 \\
\hline 7 & 54 & & 337 \\
\hline
\end{tabular}


佐藤：共有地の悲劇のシミュレーション実験

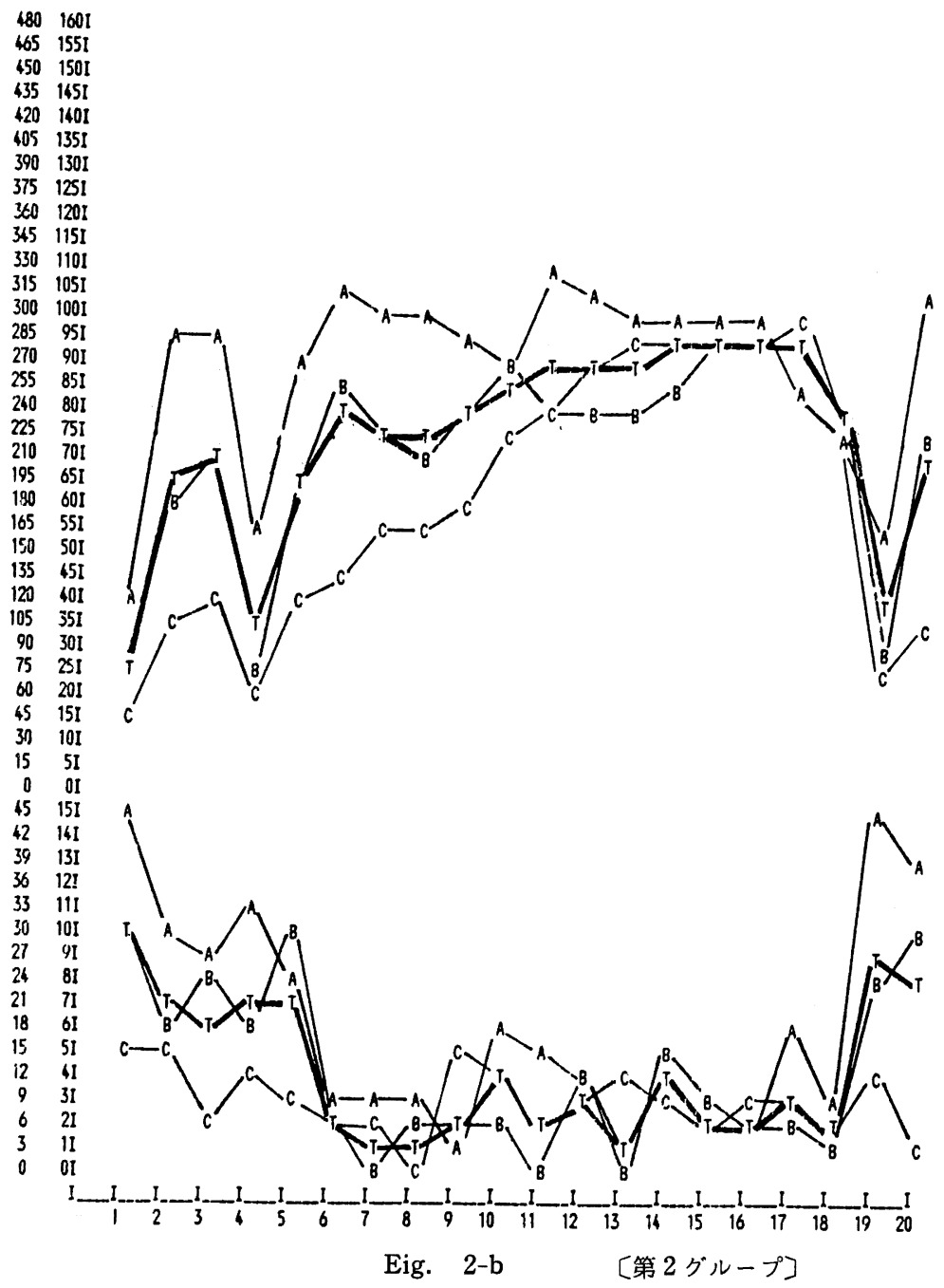

Table 2 は, 実験終了時（ないしカタストロフィーが 80武行目以降に発生しているグループでは, 最終武行が まだカタストロフィーからの回復途上にあり変化の最終 的な方向を見るために最終武行を用いるのは望ましくな いため，最後のカタストロフィーの直前試行）における 各メンバーの所有羊数の比率を示している。ての表にも 示されているように, 第1〜5 グループにおいてはメン バー間の羊数がほほ等しくなっているのに対して，第 6 , 7 グループでは，3名のメンバーの間に格差が存在した まま試行が経過している。またてれら 2 群の間には，所 有羊数の格差が解消する方向に向かうかどうかに差があ るだけでなく，ての差がメンバーの投資行動に与える影 響にも差が存在する。すなわち，第 1 ～ 5 グループにお

Table 2 ゲーム終了時個別羊数相対値 (\%)

\begin{tabular}{|c|c|c|c|}
\hline グループ & $\begin{array}{c}\text { メンバー } \\
\mathrm{A}\end{array}$ & $\begin{array}{c}\text { メンバー } \\
\mathrm{B}\end{array}$ & $\begin{array}{c}\text { メンバ- } \\
\mathrm{C}\end{array}$ \\
\hline 1 & 33 & 33 & 34 \\
\hline $2^{*}$ & 33 & 34 & 33 \\
\hline $3^{*}$ & 38 & 31 & 31 \\
\hline 4 & 34 & 34 & 32 \\
\hline 5 & 32 & 34 & 34 \\
\hline 6 & 40 & 39 & 21 \\
\hline 7 & 44 & 21 & 35 \\
\hline \multicolumn{4}{|c|}{$\begin{array}{l}\text { *カタトロフィーが } 80 \text { 試行目以降に起っているため, ゲーム } \\
\text { 終了試行ではなく，最終カタストロフィー直前試行におけ } \\
\text { る羊数を用いた。 }\end{array}$} \\
\hline
\end{tabular}




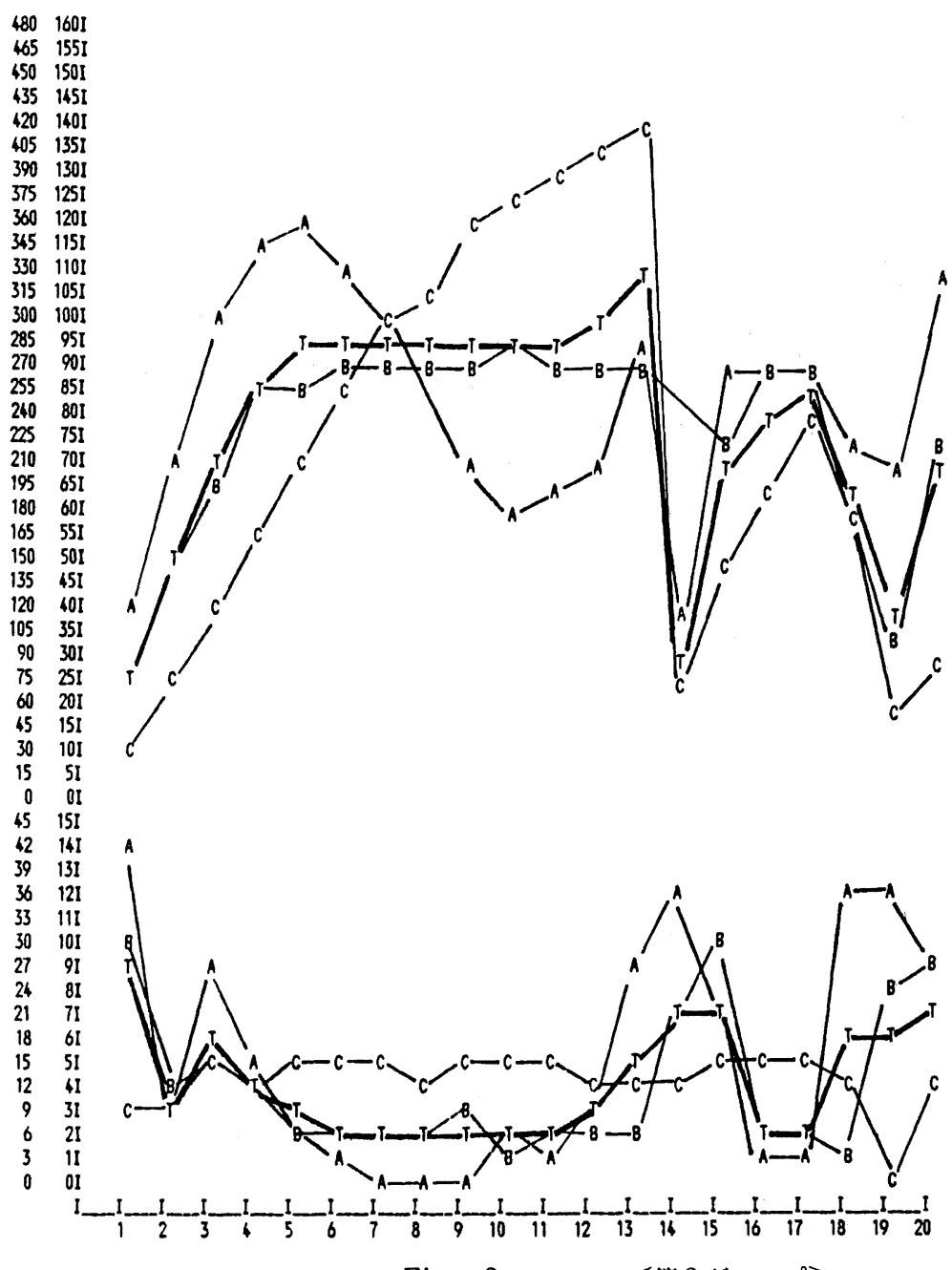

Fig. 2-c

〔第 3 グループ】

いてはメンバー間に格差が存在する場合, 羊の仕入れが 多くなる傾向にある。総羊数の少ない間は全員が常に投 資を続ける傾向にあるため，グループ全体の総羊数が 200頭を越える武行のみを取り出し，最も多くの羊を所 有するメンバーの羊数と最も少ないメンバーの羊数との 差と, 次の試行での羊の仕入れ総数との相関をとると, 第 1 〜 グループにおいてはそれぞれ .50，.28，.24, $.41 ． 32$ とかなりの相関を示している。てれに対して第 6, 7 グループにおいては，乙の相関はそれぞれ -.06, -.25となっており，羊数の格差は仕入れ数と関係がない か, むしろ格差の少ないほど仕入れ数が多くなる傾向を 見せている。すなわち最初の 5 グループでは格差の解消 をはかる方向で羊の仕入れが行なわれるのに対し, 後の
2 グループではてのような格差の解消が羊の仕入れの重 要な原因とはなっていない。

カタストロフィーの発生回数に関しては, 第 1,5 , 6, 7 グループでは一度しか発生していないのに対し， 第 $2 ， 3 ， 4$ グループでは 2 度発生している。しかして れら 2 群の間にメンバーの投資行動に大きな差は見られ ない。特に第 3,4 グループでは 1 度目のカタストロフ ィーがかなり高い水準で発生しているため, メンバーが カタストロフィーの発生水準を高く見積りすぎたととに より 2 度目のカタストロフィーが発生したものと考えら れる。カタストロフィーの発生に関して興味樑い点は, メンバー間の格差解消を目差さなかった第 6,7 グルー プがとに 2 度目のカタストロフィーの発生を経酫して 


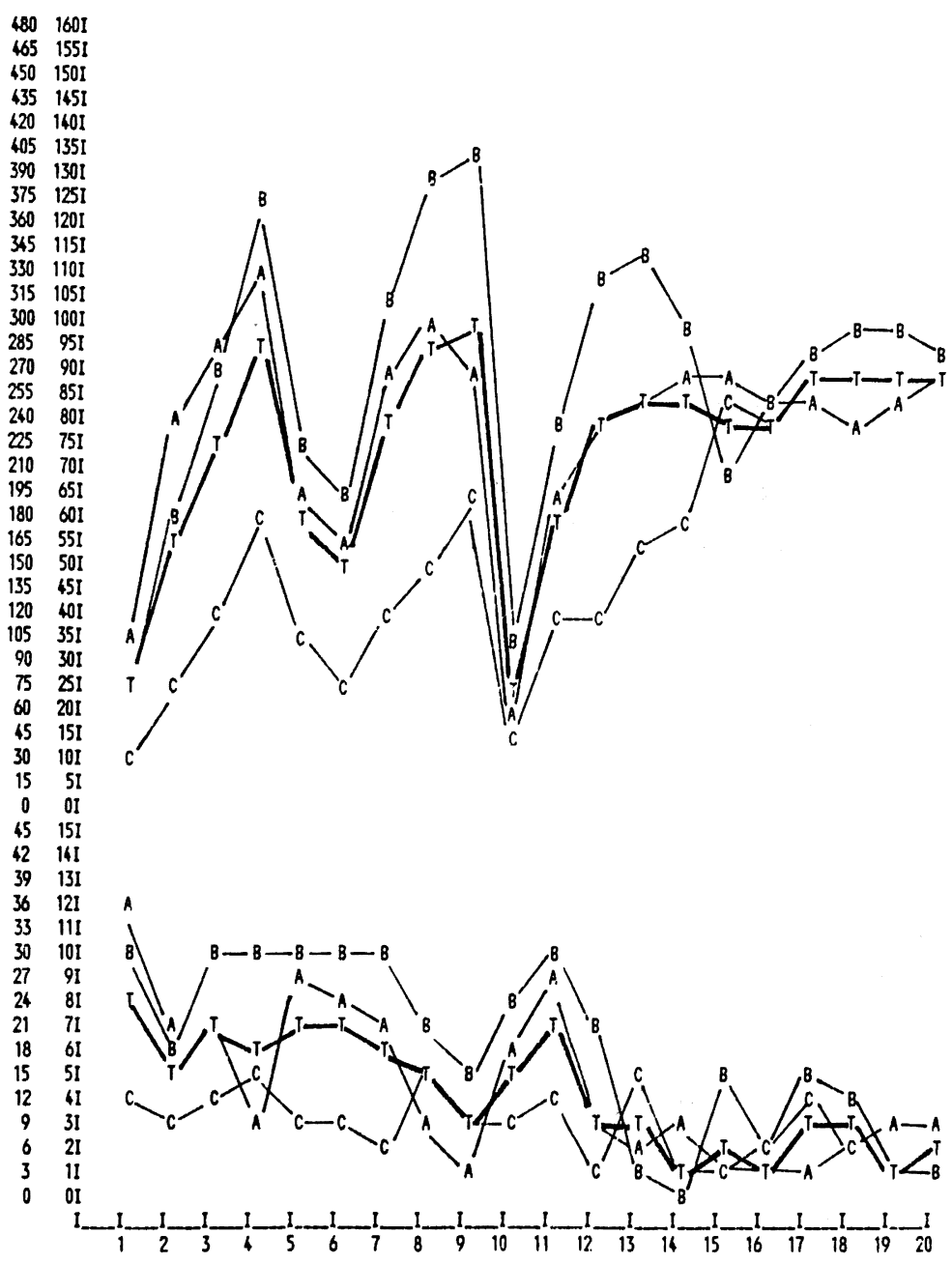

Fig. 2-d

[第 4 グループ]

いない点である。ての点に関しては, ケースの数があま りにも少なすきるためはっきりした結論を出すてとは不 可能であるが，不利な立場にあるメンバーが格差の解消 をはかって行動しない場合には資源の過剩利用が起こり にくいてとが示唆されていると考えるてとが出来るであ ろう。

取引，間引, メッセージ交換 取引が行なわれたのは 7 グループ全体で29ケースあり, 売買の平均単価は15.7 万円であった。取引にともなうメッセージの内容を検討 したとてろ，グループ全体の羊数の增加を押える目的で なされた取引はほんのわずか（1ケース）であり，従っ て今後の社会的陌せいないし共有地の悲劇に関する実験 においててのようなオプションを導入するてとにはあま
り意味がないととが示唆された。また間引行動も全グル 一プを通して3ケースしか出現しておらず，その数もあ まり多くないため(それぞれ 1 頭， 5 頭，10頭），てのオ プションも今後の実験に導入してもあまり意味がなと 考えられる。

メッセージはかなり活用されており，その内容は， 「情報要求型」,「指示・命令型」,「情報提供・忠告型」等 に大別される。今後の研究においてはメッセーシの伝達 をメニュー方式を使って行なうことにより，それぞれの 型のメッセージが資源維持に対して果している役割を組 織的に研究するてとが可能であろう。またメッセージに 関して興味のある知見は，2 度のカタストロフィーを経 験している第 $3 ， 4$ グループに拉てメッセージ交換は 


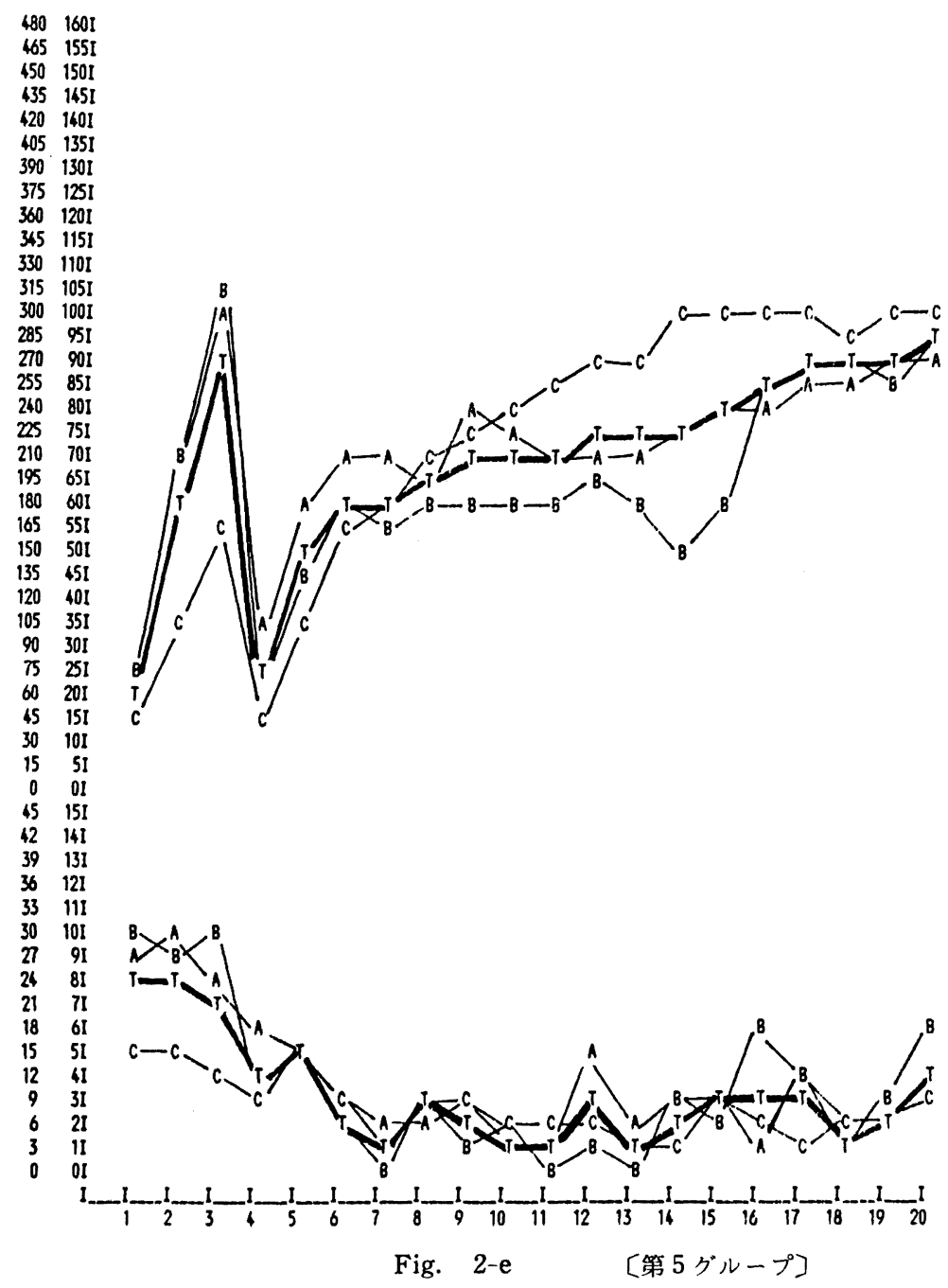

取引の際の 1 回限りしか行なわれておらず,メッセージ がほとんど活用されていない点である。社会的陷せいに おけるコミョニケーションの重要性はてれまでも指摘さ れているが (Brechner, 1977; Jorgenson \& Papciak, 1981; Edney \& Harper, 1978a , b ), 今回の実験の結果 もてれらの研究においてと同様な傾向を示していると言 える。

\section{考察}

Parker et al. (1983) も指摘しているように，被験者 の行動を環境にフィードバックさせながら行なう社会的 陥せいの実験においては, 複雑な情報の短時間における 処理が必要とされるため, コンピューターの使用が不可
欠とは言えないまでも極めて望ましい。本研究はコンピ ュターの使用により被験者の行動を逐次環境にフィート バックさせる形で共有地の悲劇のシミュレーション実験 を行なうことにより，てのような形での実験方法を開発 するととを目的としていた。てのような実験方法の有効 性を検討するために行なわれたパイロット実験の結果, 今後の実験に際して政良すべき点が幾つか見出された。

（1）取引および間引のオプションは社会的陥せい問題の 研究にとってあまり有効な手懸りを与える可能性が少な く, 今後の実験に使用するととはあまり意味がないであ ろう。(2)メッセージの交換は被験者によく利用されて おり，また被験者の行動にかなりの影響を与えるてとが 示唆された。ただし今後の研究においては，組織的な分 


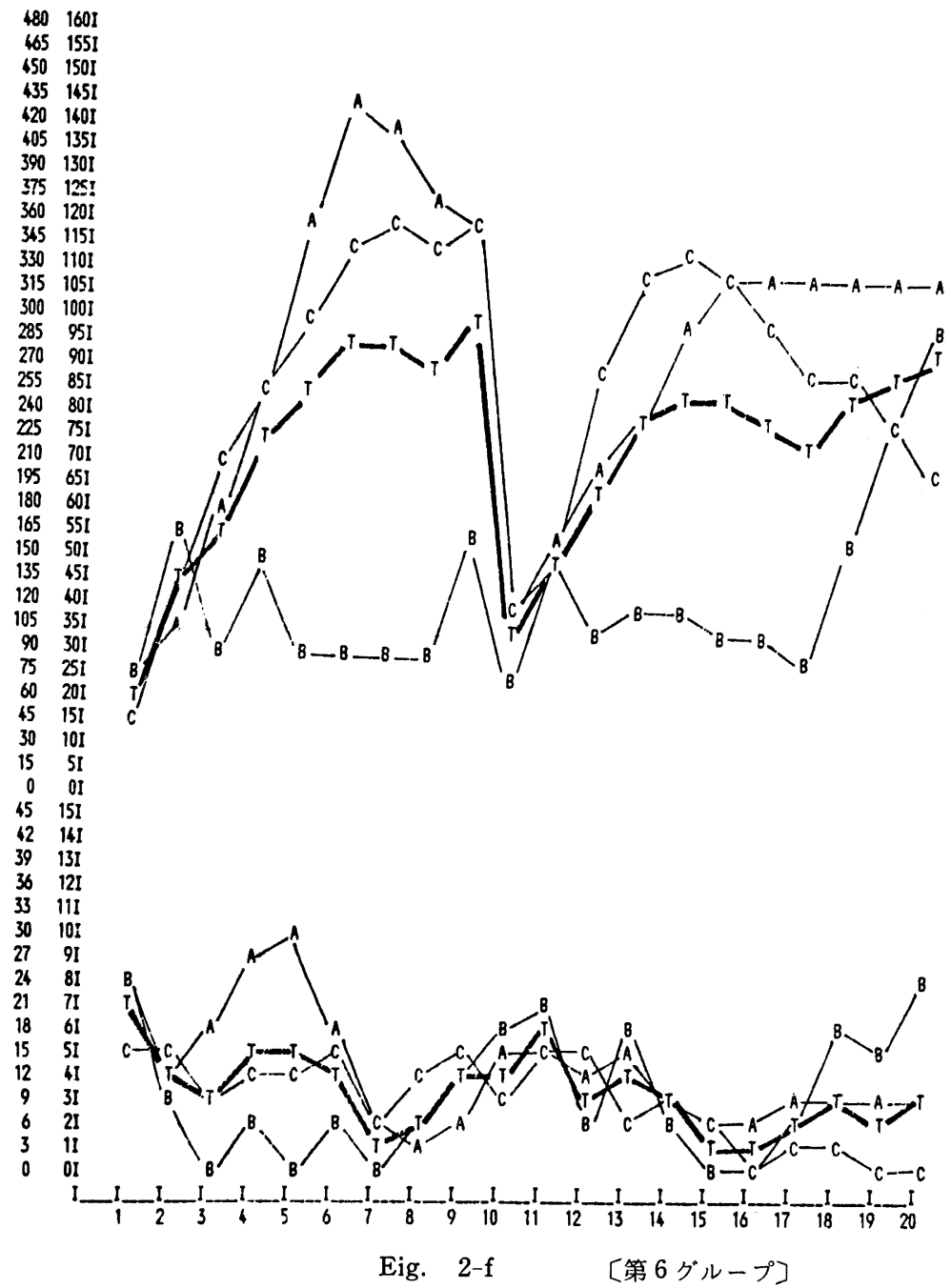

析にとって適切な形でメッセージの交換が行なわれるよ うにする（例えば幾つかのメッセージ・ライブラリーの 中から選ばせるようにする）などの改良が必要であろう。 （3）被験者の行動にグループ間のバラッキが大きく，従 って今後の研究において何らかの変数の操作の効果を調 べる場合には，乙のバラッキを少なくするための工夫が 必要となるであろう。このためにはメンバーの一部をコ ンピューターシミュレートさせるのも一つの方法であろ う。（4）カタストロフィー経験により被験者が資源の有 効利用をはかるようになるか，あるいはいつまでもカタ ストロフィーの発生を繰り返すかを調べるためには 100 試行では短かすぎる。そのような目的のための奏験には 今回の倍程度の試行数が必要であろう。（5）また今回の
実験ではカタストロフィーの発生確率が被験者に知らされ ていなかったため, 二度目のカタストロフィーの発生が, 被験者による確率の誤認によるものかそれとも危険性を 認知した上での戦略によるものか明らかにするととが不 可能であった。今回の実験の目的はこの点を明らかにす るととにあったのではないが，今後てのような目的の実 験をする場合には, 被験者による状沉の認知の効果と戦 略の影響との分離を可能とするようなデザインを用いる ことが望ましい（例えば，正確な情報を与えた群と与え られていない群を比較する等)。

また被験者間の地位の差が社会的陥せい状況における 被験者に与える影響については，(1) 不利な立場にある メンバーはグループ全体の利益よりも格差の解消を重視 


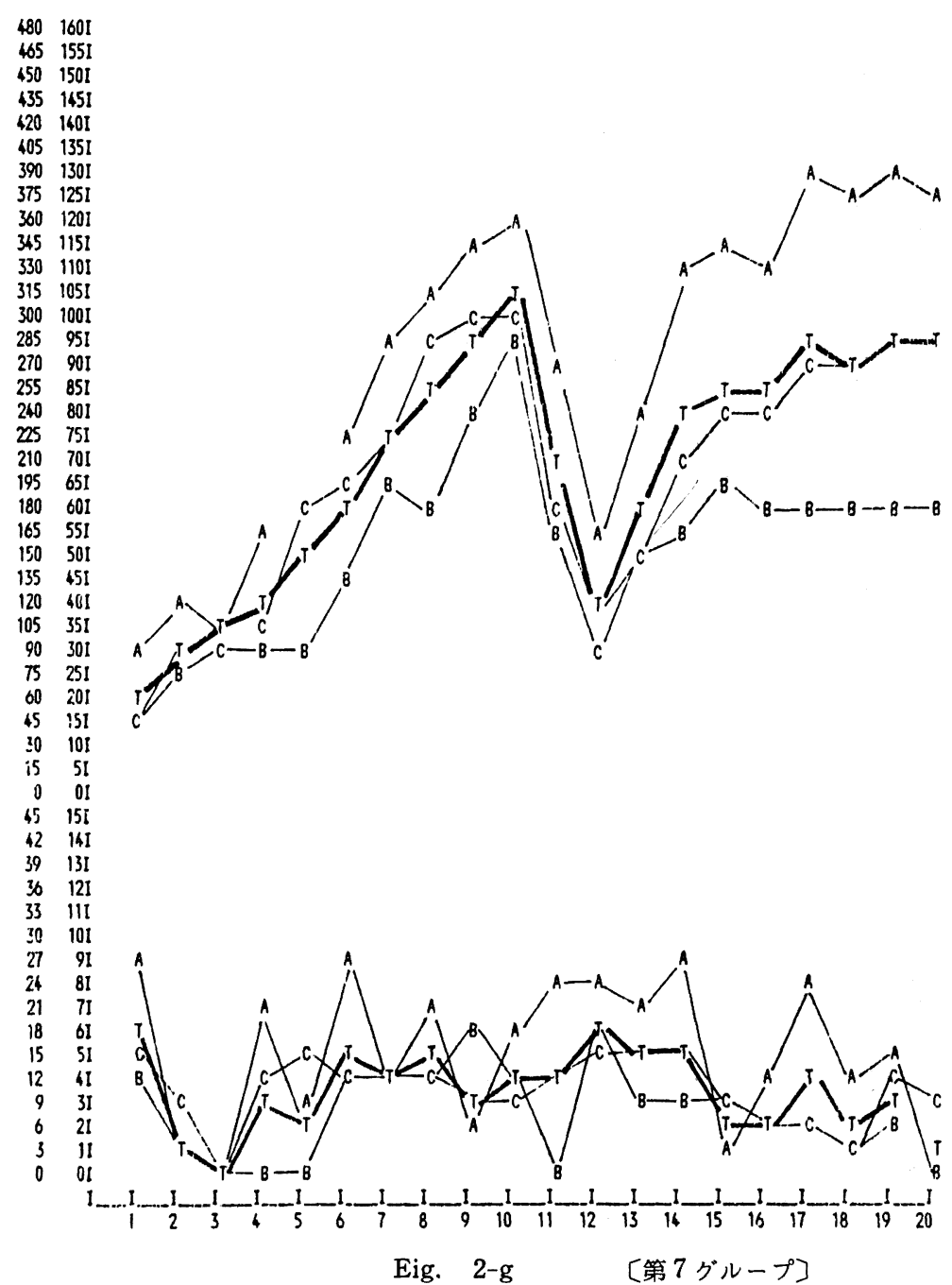

する傾向があり（7グループ中 5 グループ），このため グループ全体の資源利用度が增大する可能性のあること が示唆された。また（2）不利な立場にあるメンバーが 格差の解消をはからない場合には，資源の一定限度内で の利用が維持される傾向にあるととも示された。との関 係は現実社会においても，社会的公正を求める立場と社 会全体の効率的な運用を主張する立場との間の対立とし て存在しており, 今後の社会的陥せいに関する研究にと っての一つの重要なテーマである。従来の固定した環境 のもとで行なわれた実験においては，例えば地位の差に 応じたメンバー間の公正判断の違いを有意義な形で実験 に組み込むととは困難であり，したがって社会的公正と 社会的効率の問題に対してあまり適切な方法であるとは
考えられない。本研究に用いられた実験事態は，てのよ うな社会的公正と社会的効率との間の葛藤を研究するた めのひとつの有効な方向を示唆していると言えよう。

\section{引用 文 献}

Brechner, K.C. 1977 An experimental analysis of social traps. Journal of Experimental Social Psychology, 14, 552-564.

Chertkoff, J. M. 1970 Sociopsychological theories and research on coalition formation. In $\mathrm{S}$. Groennings, E. W. Kelley, \& M. Leiserson (eds.), The Study of Coalition Behavior. New York: Holt, Rinehart and Wilson.

Cook, K.S. \& Yamagishi, T. 1983 Social determinants of equity judgments: The problem 


\title{
佐藤：共有地の悲劇のシミュレーション実験
}

of multidimensional input. In D. M. Messick and K.S. Cook (eds.), Equity Theory: Psychological and Sociological Perspectives. New York: Praeger.

Edney, J. J., \& Harper, C. S. 1978a The commons dilemma: A review. Environmental Management, 2, 491-507.

Edney, J. J. \& Harper, C. S. 1978b Heroism in a resource crisis: A simulation study. Env. ironmental Management, 2, 523-527.

Hardin, G. 1968 The tragedy of the commons. Science, 162, 1243-1248.

Jorgenson, D. O. \& Papciak, A. S. 1981 The effects of communication, resource feedback, and identifiability on behavior in a simulated commons. Journal of Experimental Social Psychology, 17, 373-385.

-1983年 8 月 3 日 受稿, 1984年12月24日 受理一

\section{AN EXPERIMENTAL SIMULATION OF THE TRAGEDY \\ OF THE COMMONS}

\author{
KAORI SATO \\ Hokkaido University
}

\section{ABSTRACT}

In response to Edney \& Harper's (1978) criticism that the static game paradigm that has often been used in the study of social traps is not appropriate to study the dynamic aspect of the problem, a new experimental paradigm for study. ing social traps is developed, which simulates the basic characteristics of the tragedy of the commons. Since the simulation requires the constant feedback of subjects' actions to the environment, a mini-computer is used to handle the complex processing of information. Each subject seated separately in front of a computer terminal decides
\end{abstract}

how many sheep he/she adds to the common grazing ground that is graphically represented on his/her terminal screen. In a pilot experiment using this experimental format, three subjects in each group (a total of 7 groups was run) were assigned different status, allowing them to add a different number of sheep in one trial. The results of this pilot experiment were used to suggest possible improvements in the format. The results also suggest that equity concerns of the underprivileded members overrides their concern for the group welfare, culminating in repeated catastrophes.

Key words: social trap, social dilemma, tragedy of the commons, computer game, catastorophe, common interest, equity. 